\title{
Noetics in pastoral counselling: The making of a semantic differential analysis in pastoral care and counselling
}

\begin{abstract}
Author:
Daniël J. Louw ${ }^{1}$

Affiliation:

${ }^{1}$ Department of Practical Theology \& Missiology, University of Stellenbosch, South Africa

Correspondence to:

Daniël Louw

Email:

djl@sun.ac.za

Postal address:

171 Dorp Street,

Stellenbosch 7600,

South Africa

Dates:

Received: 24 Jun. 2010

Accepted: 06 May 2011

Published: 16 Sept. 2011

How to cite this article: Louw, D.J., 2011, 'Noetics in pastoral counselling: The making of a semantic differential analysis in pastoral care and counselling', Verbum et Ecclesia 32(1), Art. \#411, 5 pages. doi:10.4102/ ve.v32i1.411
\end{abstract}

(C) 2011. The Authors. Licensee: OpenJournals Publishing. This work is licensed under the Creative Commons Attribution License.
Praxis in pastoral care and counselling entails more than merely practice and practicalities (communication skills). Praxis refers to the intentionality within human action and behaviour. Praxis exhibits the realm of intentionality and meaning as displayed within and by human attitudes. It is hypothesised that due to the noetic dimension in human actions, the making of a pastoral diagnosis (a qualitative assessment of the impact of Christian spirituality and the meaning on the system of existential, relational networking) should deal with the realm of significant and purposeful intentionality. The latter is already implied in the phenomenological approach of Edmund Husserl's eidetic observation or inspection (phenomenological consciousness). In order to incorporate noetics in pastoral care and counselling, a pastoral semantic differential analysis (PSDA) within the making of a pastoral diagnosis was proposed. The PSDA was linked to the need for a qualitative approach regarding the impact of Godimages on religious association and existential life experiences.

\section{Introduction}

Besides the realm of self-transcendence another important domain should get attention in pastoral care and counselling, namely noetics. Noetics differs from moral guidance in the sense that whilst moral guidance focus on habit and virtue ${ }^{1}$ (Sperry 2002:70) in the formation and transformation of the spiritual life ${ }^{2}$, noetic counselling's aim is to probe into the realm of the significance and appropriateness of philosophies of life, belief systems and God-images that function as driving forces (motivational impulses) in human decision making, existential discernments and the finding of meaning and significance in life.

With noetic is meant the meaning of things as expressed in intentionality ${ }^{3}$, consciousness and rationality ${ }^{4}$. Noetics is therefore closely related to verbal conceptualisation and metaphorical expressions as containers of paradigms, that is, patterns of thinking and the raison d'être [reason for existence] within human actions.

\section{The noetic dimension of life issues}

Within philosophy it was Edmund Husserl who pointed out that phenomena cannot be deprived from the dimension of intentionality and meaning. Over against the empiricism with its focus on reality as merely a factual reality to be observed [en-soi], Husserl poses that the observation of phenomena is embedded in a dialectic network of noësis [the awareness of meaning], and nоёma [object of observation with reference to its intended meaning]. Within this dialectic noetics, knowledge is involved in intentionality and the process of meaning-identification.

Noetics is derived from the Greek nous [human soul, mind, intellect, understanding, reason, thought] and the verb noeō [apprehend, perceive, understand, gain insight into]. The Hebrew bin [to understand, perceive] inter alia refers to a process of judging and exploring the relation of things to one another (Harder 1978:124). As an indication of the soulfulness of our being human, nous is closely related to the function of making a true discernment in terms of awareness of the presence of God and the knowledge pertaining to the meaning and destiny of life as it emanates from this very specific awareness and wisdom [sapientia]. One can assume that the Bible gives to

1.See Sperry's taxonomy of virtues (2002:78-89) which includes charity and holiness; prudence; self-care and compassion; trustworthiness; fidelity; justice; fortitude and courage; temperance; physical fitness.

2.See Sperry's taxonomy of spiritual practices (2002:63-67) which includes purifying motivation; cultivating emotional wisdom; living ethically; developing a peaceful mind; recognising the sacred in all; cultivating wisdom and spiritual intelligence; engaging in the service of others.

3.The notion of noetics and its relatedness to intentionality stems from the phenomenology of Edmund Husserl. 'Husserl's epochè, on the contrary, makes the world (the sense of the world) appear and discloses the essential structure of phenomenological consciousness which is intention' (Thèvenaz 1962:103).

4.The notion of noetics is not new. Already in the early 1950s Viktor Frankl introduced 'noetics' by referring to 'logos' (intentionality) in his attempt to design his 'logotherapy'. See his Man's Search for Meaning. 
nous $^{5}$ and other related concepts its own interpretation. In the Bible nous refers to inter alia nefesh. It indicates the whole of human life; it describes the quality of our being human as it is determined by the covenantal presence of the Living God. Nous as related to the wisdom literature in the Bible is firmly associated with the human will (intentionality) as the locus of understanding the will of God.

Understanding in terms of Christian spirituality cannot be separated from an understanding of God's will in salvation. 'Understanding itself becomes a disposition, an attitude, and thus a standpoint of faith' (Harder 1978:127). This standpoint of faith refers to the Christian worldview of how the cross of Christ and his resurrection changed the paradigm of salvation and therefore also the paradigm of power as related to the realm of destiny and purposefulness.

In the light of the previous exposition one can say that noetics, as a variant of nous [human soul, mind, intellect, understanding, reason, thought], represents the spiritual faculty of the human mind which has the ability to discern the will of God for meaningful living. With this spiritual awareness pastoral care and counselling should reckon in processes of communication and healing when pastoral care giving wants to move from the traditional paradigm of cura animarum [care of human souls] to the networking paradigm of cura vitae [healing of life].

Noetic therapy in counselling is indeed related to communication, talking and verbalising. These functions are all actions within the realm of encounter and relationships. They represent our quest for naming and meaning in order to grasp and understand reality. One can even say they are containers of ideas in order to understand the meaning of life. Within our experience of life and the attempt to understand through perceiving and observing (the empirical endeavour) one must reckon with the action of conscious expression. The Latin intelligere refers to this dimension of 'spiritual awareness' as an event of understanding and interpreting the observed experience (Luijpen 1964:133) as well as an expression of 'idea'. Expression, talking, communication and interpretation cannot be separated from verbalising, verbal expressions. ${ }^{6}$

Talk therapy and addressing basic human needs, and learning how to verbalise life issues or life problems are all basic ingredients of the pastoral conversation. Verbalisation cannot be separated from concepts, paradigms, belief systems and meaning (the noetic dimension of healing), the logic of philosophical argumentation, as well as the philosophical

5.The understanding of the nous has particular reference to the Old Testament scriptures. The risen Christ opened the minds of the disciples so that they might understand the scriptures (Lk. 24:45 \& Harder 1978:129.

6.Verbal expressions are related to verbum. See the scholastic understanding of verbum (Luijpen 1964:134) reflection on the meaning, purposefulness and destiny of life (philosophical counselling).

Through communication and within the dynamics of relationships one starts to formulate moral codes, images, perceptions, imperatives and an understanding of aesthetics, as well as notions of what is good, true, beautiful and trustworthy. Communication and conceptualisation are the matrices within which society functions (Ellens 1987:68) and within which we progress and grow along the noetic continuum.

Ellens (1987:69) works with a very helpful model of communication, using the notion of 'healing relationality'. He identified the following six loci of the noetic continuum.

The identification of the six loci of the noetic continuum is most helpful in pastoral care and healing, because it helps the caregiver to understand the different needs at stake in addressing spiritual issues. The pastoral question is how the categories of telos [purposefulness], logos [meaning], intimacy, eschaton [the essence of our new being in Christ], promissio [the fulfilled promises of God's word], diakonia [service] and koinonia [fellowship of believers] can be linked to the other loci and needs, so that meaning can be established in the counselling and communication process.

Healing through communication often implies a deconstruction of fixed perceptions and concepts. Changing rational and noetic categories and investing them with new content and meaning is an important ingredient of the process of healing in pastoral care. In a hermeneutical approach, healing implies how one can connect life and existential issues with the spiritual realm of the content of the Christian faith. One can call this approach 'spiritual existential networking'. The healing implies the understanding of the interconnectedness spiritual categories and existential categories as well as how spiritual categories can assist human beings in their quest for meaning.

Within Christian spiritual healing, God-images and their appropriateness play a fundamental role. The question however is: how can one apply noetics within the practice of pastoral care and spiritual healing?

\section{Towards a noetic assessment of the appropriateness of God-images: A pastoral semantic differential analysis (PSDA)}

Charles Osgood (1969:4) designed a semantic differential analysis in order to study the semantic processes involved in the different meanings given to concepts and their impact on

TABLE 1: Noetic continuum in communicative healing.

\begin{tabular}{|c|c|c|c|c|c|}
\hline A: Psychological need & B: Theological need & C: Philosophical need & D: Ethical need & C: Moral need & D: Aesthetic need \\
\hline $\begin{array}{l}\text { 1. Intimacy (fear of rejection) } \\
\text { 2. Sensation of loss } \\
\text { 3. Alienation }\end{array}$ & $\begin{array}{l}\text { 1.Projected God concept } \\
\text { 2.Perception of God } \\
\text { 3. Trust, security, } \\
\text { reconciliation }\end{array}$ & $\begin{array}{l}\text { 1. Universalising meaning } \\
\text { 2. Construction of world } \\
\text { view } \\
\text { 3. Rationality and existential } \\
\text { orientation }\end{array}$ & $\begin{array}{l}\text { 1. Coherence } \\
\text { 2. Authenticity } \\
\text { 3. Clarity } \\
\text { 4.Belief system and code } \\
\text { of conduct }\end{array}$ & $\begin{array}{l}\text { 1. Conformity } \\
\text { 2.Duty, destiny } \\
\text { 3. Responsibility } \\
\text { 4.Style } \\
\text { a.Creativity } \\
\text { b.Flexibility }\end{array}$ & $\begin{array}{l}\text { 1. Celebration of sensitivity } \\
\text { 2.Good, true, beautiful } \\
\text { 3.Transcendent } \\
\text { meaningfulness }\end{array}$ \\
\hline
\end{tabular}


emotional associations (affective dimension). The semantic differential now provides a method whereby to assess the connotation of a given concept (the noetic dimension) and the emotional impact of this concept as related to religious experiences.

It will be argued here that this qualitative approach can be most helpful in situations where the pastoral caregiver wants to support believers to gain more clarity regarding the interplay between God-images and the religious interpretation of life events, that is, how people experience God in their daily lives in terms of spiritual perspectives and meaningful spiritual associations emanating in religious conceptualisation. Osgood's approach should therefore not be assessed as an attempt to quantify a Christian spiritual interpretation but to enhance the appropriateness of a pastoral hermeneutics, thus the attempt to adjust Osgood's model to the needs of the pastoral ministry.

According to Osgood (1969:36) such a method firstly comprises the use of factor analysis to determine the number and nature of factors entering into a semantic description and judgement, and secondly the selection of a set of specific scales corresponding to these factors which can be standardised as a measure of meaning.

Standardisation is made possible because of the general hypothesis that concepts have an affective and thus also an existential meaning. The affective power of a word has a dimensional structure, which may be researched. It is divided into three main dimensions: 'evaluation, activity and potency' (Osgood \& Suci 1969:130). This measuring of meanings should be viewed within the psychological and existential impact of concepts as well as against the background of processes of symbolising. It should not be regarded as a final classification of the linguistic meaning of a concept (Osgood \& Suci 1969:130).

The research of Fishbein and Raven (1967:184) identifies a fourth dimension: the dimension of probability. This dimension refers to the component of reality. Hence their proposal to change the Osgood scales. They identify the following five experiential belief items: 'probableimprobable; possible-impossible; likely-unlikely; existentnon-existent; true-false' (1967:184).
It is my contention that the findings of Fishbein and Raven could be used to amplify a pastoral semantic differential analysis (PSDA). Applied to God-images and belief items, it touches the problem of the probability and likelihood of God and the need to assess the quality of religious associations within a pastoral hermeneutics. Is the understanding and interpretation of God in a specific existential setting appropriate or not, and how does the interpretation of God affect human's spirituality and attitude?

A PSDA has value for a pastoral theology; because it enables people's understanding of God to be assessed. Semantic differential (SD) thus promotes the process of understanding in communication. In order to determine the meaning of concepts, opposite meanings should be identified. In this way a general group of contrasting concepts and adjectives may be identified and then applied to all concepts. For example, the evaluation category has the following pairs of contraadjectives: beautiful-ugly, pleasant-unpleasant, clean-dirty, nice-disgusting. The potential category: strong-weak, largesmall, heavy-light. Activity category: immediate-delayed, active-passive, quick-slow. Probability category: possible (real)-impossible (unreal, imaginary), likely-unlikely, existent-non-existent, true-false.

The difference between Osgood's initial model and the PSDAmodel resides in the fact that a pastoral semantic differential analysis focuses more on the cognitive associations (content of faith) and the hermeneutical background of belief systems (see, for example, the influence of doctrine and confessions of faith on God-images) of the parishioner's understanding of the concept 'God' than on merely the affective associations. This focus does not mean that such a cognitive understanding (belief items) necessarily excludes affective associations.

The following diagram gives an indication of a PSDA to be applied in philosophical and noetic counselling.

The following question surfaces: How should the PSDA be applied in pastoral caregiving within the context of ministry and counselling?

The pastor could use a PSD in the following way. Parishioners are asked to evaluate the concept 'God' against the designated scale. They should be encouraged to

TABLE 2: Reality of God-experiences and associations.

\begin{tabular}{|c|c|c|c|c|c|c|c|c|}
\hline Probable & +3 & +2 & +1 & 0 & -1 & -2 & -3 & Improbable \\
\hline Possible or real & - & - & - & - & - & - & - & Impossible or fictitious \\
\hline Likely or knowable & - & - & - & - & - & - & - & Unlikely or unknowable \\
\hline Existent or conceivable & - & - & - & - & - & - & - & Non-existent or inconceivable \\
\hline True or personal & - & - & - & - & - & - & - & Vague or general \\
\hline
\end{tabular}

TABLE 3: Value of God-experiences and associations.

\begin{tabular}{|c|c|c|c|c|c|c|c|c|}
\hline Empowering & +3 & +2 & +1 & 0 & -1 & -2 & -3 & Hampering or disempowering \\
\hline Just/fair & - & - & - & - & - & - & - & Unjust or unfair or biased \\
\hline Faithful/trustworthy & - & - & - & - & - & - & - & Unfaithful or untrustworthy \\
\hline Loving & - & - & - & - & - & - & - & Hostile \\
\hline Steadfast & - & - & - & - & - & - & - & Inconsistent \\
\hline Approachable or merciful & - & - & - & - & - & - & - & Unapproachable or merciless \\
\hline
\end{tabular}


TABLE 4: Potential within God-experiences and God-images.

\begin{tabular}{llllllll}
\hline Strong & +3 & +2 & +1 & 0 & -1 & -2 & -3 \\
\hline Omnipotent & - & - & - & - & - & - & - \\
Sympathetic or compassionate & - & - & - & - & - & - & - \\
Clear (will of God) & - & - & - & - & - & - & - \\
\hline
\end{tabular}

TABLE 5: Efficiency of experiences with God as related to activity.

\begin{tabular}{|c|c|c|c|c|c|c|c|c|}
\hline Active & +3 & +2 & +1 & 0 & -1 & -2 & -3 & Passive \\
\hline Presence or proximity & - & - & - & - & - & - & - & Distance or absent \\
\hline Redeeming & - & - & - & - & - & - & - & Rejecting \\
\hline Blessing & - & - & - & - & - & - & - & Accusing \\
\hline Assisting or helping & - & - & - & - & - & - & - & Withdrawing \\
\hline
\end{tabular}

think about their immediate experience of God firstly, and then to concentrate on their association between God and events during the past. It should be explained to them that appropriate (positive)-inappropriate (negative); probablyimprobable; empowering-hampering; strong-weak; activepassive are not ethical categories that reflect good or bad. As both appropriate and inappropriate interpretations of God could play an important role in parishioners' development of spirituality, they should not attempt to avoid remembering negative associations of God. Parishioners must answer honestly. They should also not feel that they must recall exemplary associations with God; in an attempt to make these fit the expectations of the church (denominational confessions). Each person's immediate association and experience of God is important.

It should be notified here that this assessment is not applicable in situations of crises and for the identification of problems or 'spiritual pathology'. The assessment is applicable in settings where the pastoral ministry want to focus on prevention and to assist believers in their journey to spiritual maturity and spiritual growth.

It is also paramount to note that the PSDA is not a quantitative method to be used in order to 'prove', 'verify' or to be applied in statistics. It is basically a hermeneutical exercise to assist believers when they are not in a crisis to get clarity on the impact of their association and understanding of God on their immediate experience of God. The information should be used as a flow chart, which can help parishioners to reflect on the quality of their relationship with God. As a hermeneutical 'tool' the spiritual knowledge and insight gained by this exercise must be used in pastoral counselling to enhance spiritual growth and a mature faith. For example, with the fourth category on efficiency the adjectives 'presence-distance' can give an indication of the interplay between immediate life events and the experience of God. Here people often refer to God as near or far. These references are not ontological qualities regarding the being of God, but experiential categories in terms of the flow of life events.

The flow of pastoral counselling can be divided into four stages $^{7}$ (Louw 2009:252-253):

7.The stages do not follow one after another (linear). They are cyclic or spiral and merely hermeneutical. They should be used as general guidelines.
1. the listening stage (feeling)

2. the interpretation stage (thinking which entails identifying the problem and dealing with facts and information)

3. the active stage (doing and goal setting)

4. the spiritual stage (believing which entails empowerment and the application of sources of faith - prayer, Bible reading, reflection, holy communion).

The PSDA can be used in moving from the interpretative stage into the action stage. It can help people to gain insight in their spiritual sources. It also stimulates reflection and talking about life events and the interplay between faith and believing: professing the faith.

\section{Noetics in an interdisciplinary approach}

As argued, a PSDA can help the caregiver to gain clarity on the question of what the possible contribution of the content of the Christian faith to care and healing is. It illuminates the interplay between God-images and the human quest for meaning. Within psychology, logotherapy and rational emotive therapy (RET) could be viewed as variants of noetic counselling within the discipline of psychology. They should be assessed as complementary to a PSDA.

\section{Logotherapy}

Even in psychology the dimension of noetics has been recognised as an important factor in therapy. In this regard Viktor Frankl's logotherapy should be mentioned. R.C. Leslie wrote a book Jesus and logotherapy in order to link Frankl's approach to Christian spiritual care. He states 'while the task of psychotherapy is to uncover the psychological background of an ideology, the task of logotherapy is to reveal the flaws in improper logical grounds for a world-view and thereby to effect a readjustment' (1965:114). Leslie's basic premise was that 'Jesus gave primary attention to correcting a wrong view of life' (1965:113). Logotherapy was an attempt to translate psychotherapy in 'spiritual terms' (Frankl 1969:11). Its focus is the destiny of humankind and the position (attitude) one takes. This 'position taken' or attitude is, in contrast to the basically destined 'position given', a matter of free choice (Frankl 1969:80). It was therefore the viewpoint of Frankl (1969) that logotherapy must supplement psychotherapy: 
by the use of logotherapy we are equipped to deal with philosophical questions within their own frame of reference, and can embark on objective discussion of the spiritual distress of human beings' suffering from psychic disturbances.

(Frankl 1969:17)

His presupposition is that instead of the 'will to pleasure' the 'will to meaning' is the primary motivational force in human beings (Frankl 1975:154). For Frankl logos [meaning] denotes meaning and focuses therefore on the future, attitudinal values, as well as 'man's search for meaning' (Frankl 1975:153-154).

\section{Rational Emotive Therapy}

Whilst logotherapy concentrates mainly on the meaning dimension and intentionality, Rational Emotive Therapy (RET) focuses more on irrational thinking and the impact of must-messages (absolute categories) on self-understanding and self-evaluation. The psychologist Albert Ellis (1977:15) therefore defines irrational concepts as any thought, emotion, or behaviour that leads to self-defeating or selfdestructive consequences that significantly interfere with the survival and happiness of the organism. In his ABC-model for counselling his presupposition is that an activating experience or event (A) and the emotional consequences for behaviour $(\mathrm{C})$ are determined by very specific rational categories, values, norms and attitudes as embedded in belief systems that are functioning in an absolute prescriptive way (1977:6-7). Change is directly related to the interpretation of events and a very specific conviction or philosophical schema of interpretation.

\section{Conclusion}

Noësis in noetic counselling refers to the meaning dimension of life issues, their functionality in terms of intentionality.

The assumption in noetic healing and therapy is that in order to change an attitude one must change inappropriate paradigms. A paradigm is appropriate when it empowers people to make informed decisions and to take responsibility for their lives [respondeo ergo sum] in terms of meaning and destiny. One cannot change what happens and befalls one; however, one can change how one interprets the event and responds, thus the necessity to probe into the character and normative dimension of belief systems, which incorporates the value dimension of life.

The practice of a noetic assessment in a pastoral diagnosis is closely related to rational emotive therapy (RET) and logotherapy in psychology. Noetic counselling within a Christian spiritual approach incorporates the pastoral diagnostic process of the assessment of God-images. In this regard, a pastoral semantic analysis can be applied. It should be used in the care-giving ministry as a qualitative approach to a pastoral hermeneutics within processes of spiritual growth towards spiritual maturity.

\section{References}

Ellens, J.H., 1987, Psychotheology: Key Issues, University of South Africa, Pretoria.

Ellis, A.R. Grieger, 1977, Handbook of rational emotive therapy, Springer Publishing Company, New York, NY.

Fishbein, M.B. \& Raven, B.H., 1967, 'The AB scales: An operational definition of belief and attitude', in M.B. Fishbein (ed.), Readings in attitude, theory and measurement, pp. 180-190, John Wiley \& Sons, New York, NY.

Frankl, V., 1975, Man's search for meaning, Pocket Books, New York, NY.

Frankl, V., 1969, The doctor and the soul. From psychotherapy to logotherapy, Souvenir Press, London, UK.

Harder, G., 1978, 'Nous [reason]', in C. Brown (ed.), Dictionary of New Testament Theology, Vol III, pp. 122-130, Paternoster Press, Exeter.

Harder, G., 1978, 'Soul', in C. Brown (ed.), Dictionary of New Testament Theology, Vol III, pp. 686-687, Paternoster Press, Exeter.

Leslie, R.C., 1965, Jesus and logotherapy, Abingdon, Nashville, TN.

Luijpen, W., 1964, Existentiële fenomenologie [Existential phenomenology], AulaBoeken, Utrecht.

Louw, D.J., 2008, Cura Vitae. Illness and the Healing of Life, Lux Verbi, Wellington.

Osgood, C.E. 1969, 'The nature and measurement of meaning', in J.G. Snider \& C.E. Osgood (eds.), Semantic differential technique, pp. 10-40, Aldine, Chicago.

Osgood, C.E. \& Suci, G.J., 1969, 'Factor analysis of meaning', in J.G. Snider \& C.E. Osgood (eds.), Semantic differential technique, pp. 129-135, Aldine, Chicago, IL.

Sperry L., 2002, Transforming Self and Community. Revisioning Pastoral Counselling and Spiritual Direction, The Liturgical Press, Collegeville, PA.

Thèvenaz, P., 1962, What is Phenomenology?, Quadrangle Books, Chicago, IL. 